Egyptian Journal of Aquatic Biology \& Fisheries

Zoology Department, Faculty of Science,

Ain Shams University, Cairo, Egypt.

ISSN $1110-6131$

Vol. 23(3): 27 - 41 (2019)

www.ejabf.journals.ekb.eg

\title{
Improvement molluscicidal activity of Anagalis arvensis extracted by copper oxide nanoparticles against Biomphalaria alexandrina snails
}

\author{
Abdel Halim A. Saad ${ }^{1}$, Ahmed M. Azzam², Bayaumy B. Mostafa ${ }^{2}$, \\ Khalil M. El-Said ${ }^{2}$ and Rasha A. Hanafy ${ }^{2}$ \\ 1- Zoology Department, Faculty of Science, Ain-Shams University, Egypt. \\ 2- Environmental Researches Department, Theodor Bilharz Research Institute, Egypt.
}

\section{ARTICLE INFO}

\section{Article History:}

Received: May18, 2019

Accepted: June 6, 2019

Online: June 9, 2019

\section{Keywords:}

B.alexandrina

Anagalis arvensis

Copper oxide

Molluscicide

Nanoparticles

Histopathology

\begin{abstract}
Nanotechnology has received more attention in the field of control of intermediate hosts. In the present study, copper nanoparticles were fabricated and characterized using scanning electron microscopy (SEM), transmission electron microscope (TEM), x-ray fluorescence (XRF) and fourier transform infrared (FTIR). Improvement of the molluscicidal activity of Anagalis arvensis ethanolic extract was made using $\mathrm{CuO}$ NPs by forming plant nanocomposite ( $\mathrm{ACuO} \mathrm{NC})$. The results showed that $\mathrm{ACuO} \mathrm{NC}$ has high molluscicidal activity against $B$. alexandrina snails; recording $\mathrm{LC}_{50}$ and $\mathrm{LC}_{90}$ were 1.76 and $3.16 \mathrm{ppm}$, respectively. Also, biochemical parameters (Total protein, ALT, AST and ALP) revealed highly significant changes in treated snails with sublethal concentrations $\left(\mathrm{LC}_{10}\right.$ and $\left.\mathrm{LC}_{25}\right)$ of $\mathrm{ACuO} \mathrm{NC}$. However, histopathological changes occurred in the hermaphrodite glands of snails exposed to these concentrations of nanocomposite were detected, where, the ova and sperms degenerated and there were losses of connective tissues between acini. ACuO NC was more safety when tested against the biological indicator Daphnia magna. These observations prove that $\mathrm{ACuO} \mathrm{NC}$ has potent molluscicidal activity against the intermediate hosts of Schistosoma mansoni with more safety for aquatic environment.
\end{abstract}

\section{INTRODUCTION}

Schistosomiasis is a widespread neglected tropical parasitic disease transmitted by snails (WHO, 2017). Freshwater snails of Biomphalaria genus are the intermediate hosts of Schistosoma mansoni in Egypt (Ibrahim and Abdalla, 2017). It has been long documented that the most important trematode disease of man is schistosomasis, also called Bilharziasis after the German physician Theodor Bilharz who discovered the causative organisms of the disease in Cairo more than 140 years ago (Bilharz, 1853).

Human infection with Schistosoma mansoni is closely related to the existence of its intermediate host of the genus Biomphalaria alexandrina snails. The distribution of these snails extended from the Nile Delta and present throughout the country along the tributaries of the Nile (Abou-El-Naga et al., 2011).

There are several strategies have been used to control snail populations through breaking the life cycle (El-Ghany and El-Ghany, 2017). Manufactured molluscicides is an imperative part in the incorporated schistosomiasis control programs (Abdel- 
Ghaffar et al., 2016), but due to they have high cost and being poisonous to creatures of land and water (WHO, 2014), have stimulated interest to find suitable plant molluscicides (Elsareh et al., 2016).

The molluscicidal activity of some plants extracts not only control the vector snail but they would also seem to be less expensive, readily available, and rapidly biodegradable and have low toxicity to non-target organisms (Adewumi et al., 2013).

Nanotechnology is the science of manipulating matter at a very small, molecular scale where dimensions and tolerances of less than 100 nanometres. It has recently been regarded as a promising field of high technologies capable of covering many vitally important spheres of human activities. The development of nanotechnology is ahead of the assessment of their impact on the environment, plants, animals and humans. Moreover, the currently available data are variegated and contradictory (Andrievsky et al., 2005; Oberdorster et al., 2005; Oberdorster et al, 2007; Wang et al., 2017).

Nanomaterials have unique properties compared with their larger counterparts. Due to small size and hence higher specific surface area of the nanoparticles, these can easily bind with and transport toxic pollutants. The synthesis of nanoparticles takes place for many applications in various fields of science, technology, medicine, drug delivery, health impacts, personal care applications (Shi et al., 2002; Sun et al., 2018).

The effect of engineered nanoparticles on aquatic organisms and the issues of penetration and accumulation of them in the body of aquatic organisms and their toxic effect, biotransformation, and migration along food webs are considered. It is demonstrated that the behaviour of nanomaterials in the environment and their effect on living organisms have been studied insufficiently and require close attention because their release into the environment will increase in the very near future (Krysanov et al., 2010).

The potential impact of NPs on aquatic ecosystems has attracted special attention due to their unique physicochemical properties (Wiench et al., 2009; Ali et al. 2012; Sales, 2013). Ecotoxicological studies on NPs are more limited, with only a few reports on the acute toxic effects of NPs on aquatic organisms (Park and Choi, 2010; Ma et al. 2013). Freshwater snails are an ecologically important species because they serve as sensitive biomarkers of aquatic ecosystem pollution (Jagtap et al., 2011).

There are many nanoparticles show significant effect as molluscicides such as zinc oxide and copper oxide nanoparticles. The potential impacts of $\mathrm{ZnO}$ NPs on aquatic ecosystems have attracted special attention due to their unique properties. It was designed to evaluate the effects of $\mathrm{ZnO}$ NPs on freshwater snail B. alexandrina. $\mathrm{ZnO}$ NPs showed molluscicidal activity on $B$. alexandrina snails, it elicited a significant decrease in the different behaviors of treated snails. These changes in behavior would potentially impact the snail's ability to survive in the field (Habib et al., 2016).

Fahmy et al. (2014) studied the highlights potential of ecological implications of $\mathrm{ZnO}$ NPs release in aquatic environments .Moreover, copper oxide nanoparticles have been used as molluscicides which have significant effect on the snail's ability to survive in the field (Handy et al., 2008; Nowack, 2009).

In the present study, testing the efficacy of synthesized $\mathrm{CuO}$ NPs in improvement the molluscicidal activity of ethanolic extract of Anagallis arvensis plant extraction was carried out. 


\section{MATERIALS AND METHODS}

\section{Material and methods}

\section{Preparation of ethanolic $A$. arvensis extract}

Anagalis arvensis was collected from Orman garden, Giza governorate during full growing spring season according to (WHO, 1965). The ethanol extract was prepared by soaking $250 \mathrm{~g}$ of dry plant powder in $1000 \mathrm{ml}$ of the ethanol in a conical flask. The mouth of the flask was covered with aluminum foil and incubated in an oven for 24 hours. After incubation time, the extract was obtained by a filtered solution using whatman filter paper (No.1). The solvent was evaporated using a water bath temperature at $50^{\circ} \mathrm{C}$ and kept in an oven at $50^{\circ} \mathrm{C}$ to dry completely. Finally, the residues were collected and the extract was stored in dry clean dark glass beaker till use (Bakry et al., 2002).

\section{Preparation of copper oxide NPs}

The copper oxide nanoparticles were prepared by precipitation method using copper sulphate as starting material. Sodium hydroxide solution (2M) was added to copper sulphate solution (1M) drop by drop touching the walls of the vessel under constant stirring $(160 \mathrm{rpm})$ on a magnetic stirrer, (JSHS-180, Korea) for 2 hours. The solution was allowed to settle overnight, and then filtrated carefully through whatman filter paper (No. 1). The precipitate was washed several times using distilled water. $\mathrm{CuO}$ NPs were dried in an oven at $50^{\circ} \mathrm{C}$ overnight (Manyasree et al., 2017) (Fig. 1).

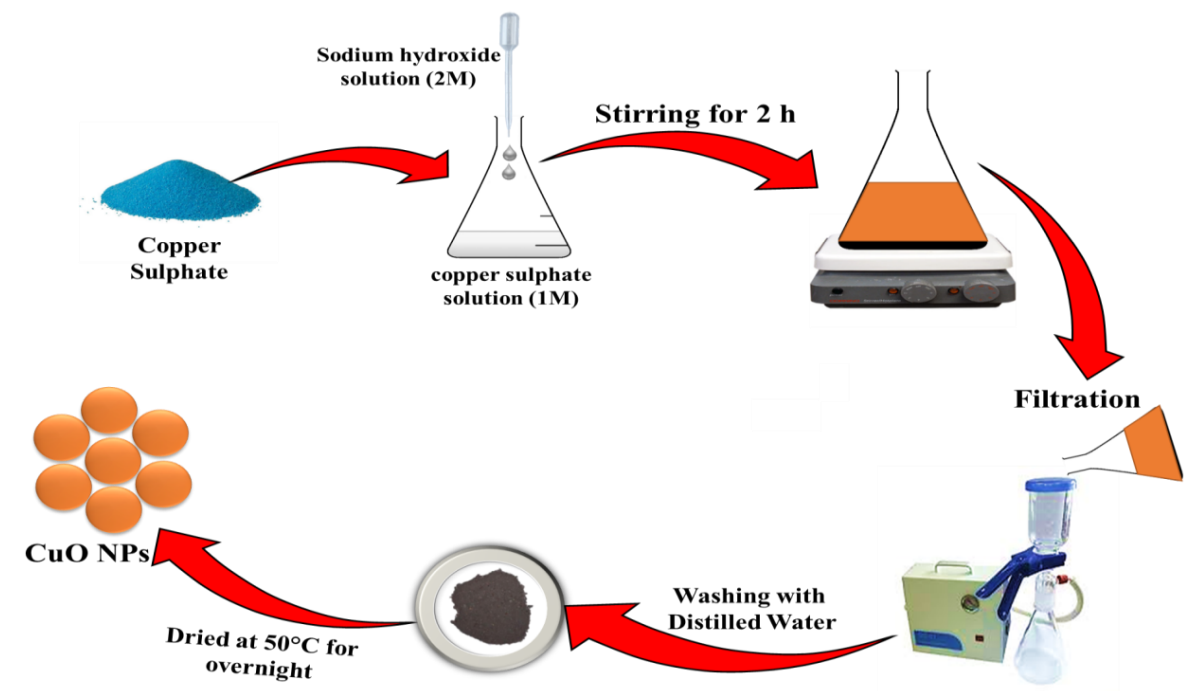

Fig. 1: Schematic diagram of copper oxide nanoparticles synthesis.

\section{Characterization of $\mathrm{CuO}$ nanoparticles and plant nanocomposite}

Prepared nanomaterials were characterized with the help of multiple techniques. Morphology of the nanoparticles was studied using scanning electron microscopy (SEM) analysis. Samples were placed on SEM grids coated with gold palladium on a pumped-rotary sputter coater Q150R ES (Quorum Technologies Ltd., USA). SEM was carried out on a JEOL JSM-7600F electron microscope (JEOL Ltd., Tokyo, Japan) at a voltage of $2.0 \mathrm{kV}$. This method is considered to examine each particle, including the aggregate particles (Lee et al., 1996).

The particles size of the resulting nanoparticles was analyzed using a transmission electron microscope (TEM) (JEOL Ltd, USA) connected to a high 
resolution imaging system. Samples for TEM studies were prepared by placing drops of nanoparticles solutions on carbon-coated TEM copper grids.

$\mathrm{X}$-ray fluorescence (XRF) that was performed to detect the main chemical elemental analysis of the minerals that are present in synthesized $\mathrm{CuO}$ nanoparticles. XRF measurements were carried out using the JSX-3222 element analyzer.

Fourier transform infrared (FTIR) spectroscopy of nanoparticles and nanocomposites were analyzed using Nicolet iZ10, thermos-Scientific, Waltham via the $\mathrm{KBr}$ pressed disc method, in the spectral region of 4000 to $400 \mathrm{~cm}^{-1}$ wave numbers.

\section{Fabrication of plant extract nanocomposite}

Following the method of (Rostami-Vartooni et al., 2015), $0.2 \mathrm{~g}$ of the $\mathrm{CuO}$ nanoparticles was added to $35 \mathrm{ml}$ ethanol under condition of heating $40^{\circ} \mathrm{C} \pm 1$ with stirring $(200 \mathrm{rpm})$ for $15 \mathrm{~min}$, then $25 \mathrm{ml}$ Glutaraldehyde solution $(25 \%)$ was added as cross a linkage agent with vigorous stirring for 6 hours (Hotplate and magnetic stirrer, JSHS-180, Korea). After that, the precipitate was filtered and washed three times with ethanol. The precipitate was put in clean flask, then $100 \mathrm{ml}$ ethanol was added with stirring $(200 \mathrm{rpm})$, after that the ethanolic A. arvensis extract was added dropwise, at $40^{\circ} \mathrm{C} \pm 1$. The formed nanocomposite (NC) was filtrated and washed with ethanol three times to remove any unlinked compounds. The nanocomposite dried in an oven at ${ }^{\circ} 0^{\circ} \mathrm{C}$ overnight and stored until testing its molluscicidal activity (Fig. 2).

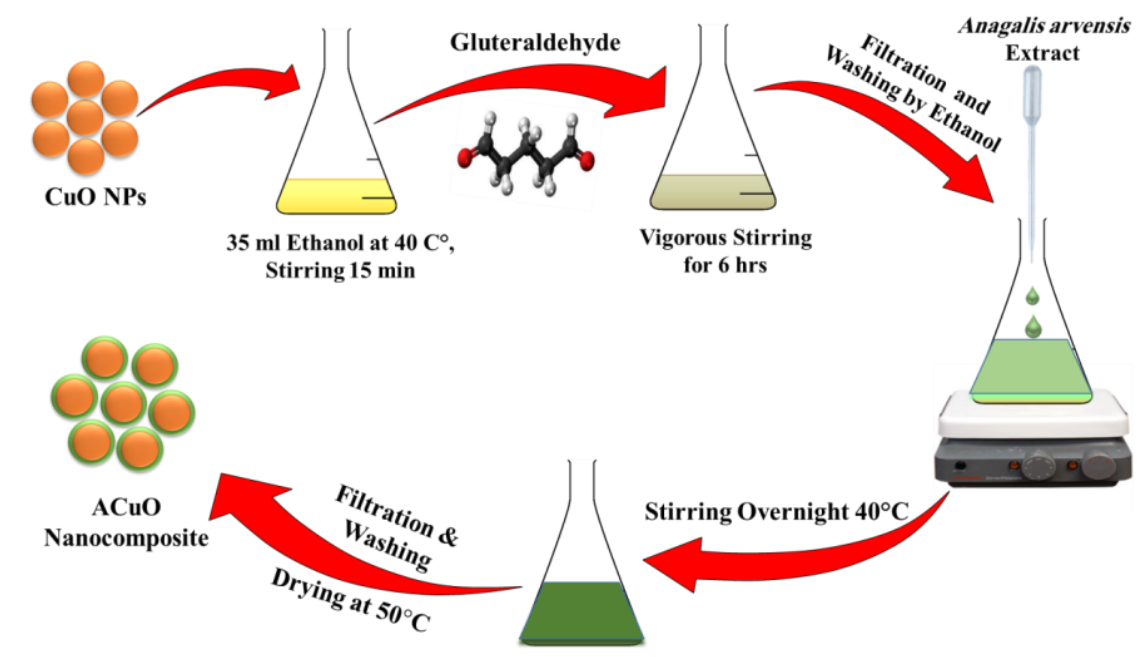

Fig. 2: Schematic diagram of plant-nanocomposite synthesis.

\section{Detection of molluscicidal activity}

The snails used in the present work were $B$. alexandrina, the snail intermediate host of Schistosoma mansoni, they were collected from canals in Giza governorate, Egypt during the spring season, 2017. Snails kept for four weeks under laboratory conditions before used to accommodate to these conditions. To estimate the lethal doses, series of concentrations expressed in terms of ppm were prepared for $A$. arvensis ethanolic extract, $\mathrm{CuO}$ nanoparticle and nanocomposite on the basis of weight/volume using dechlorinated tap water (Borai et al., 2005). Three replicates of one hundred snails were exposed for target concentrations for 24 hours each and then recovered for another same time. Control snails were maintained under the same experimental conditions in dechlorinated water. Snail mortality was confirmed by immersion tested snails in sodium hydroxide solution (20\%) (Nolan et al., 1953). The result was calculated as the average of these replicates. The test was carried out at 
room temperature using water with $\mathrm{pH} 7.0$ and TDS $235 \mathrm{ppm}$. The molluscicidal agent tested has been expressed in terms of lethal concentrations values via statistical analysis.

\section{Effect of some environmental factors on molluscicidal activity of $\mathrm{ACuO} \mathrm{NC}$}

It was necessary to determine the molluscicidal activity of $\mathrm{ACuO} \mathrm{NC}$ against snails at a different temperature, $\mathrm{pH}$ and TDS. The temperature $\left(15,25\right.$ and $\left.30{ }^{\circ} \mathrm{C}\right)$ were adjusted using a water bath (Lemma, 1970). $\mathrm{pH}$ concentrations (5, 7 and 9 ) were prepared using $0.1 \mathrm{M}$ sodium hydroxide solution or $0.1 \mathrm{M}$ hydrochloric acid solution (Salah El-Din, 1999). Different TDS (300, 600, 900 and 1200 ppm) were prepared using sodium chloride solution, $\mathrm{pH}$ and TDS values were adjusted using $\mathrm{pH}$ and TDS Bench meter (Romania) (Wetzel et al; 2001).

\section{Effect of $\mathrm{ACuO} \mathrm{NC}$ on biochemical parameters of $B$. alexandrina}

Biomphalaria alexandrina snails were exposed to $\mathrm{LC}_{10}$ and $\mathrm{LC}_{25}$ of $\mathrm{ACuO}$ NC for two weeks (Bakry, 2009). Three replicates of one hundred snails were exposed for each concentration, hemolymph was collected from these treated groups (each replicate in Eppendorff vial) and another group was maintained in dechlorinated water as control (Sminia, 1972). Hemolymph of the snails were collected by using the techniques described by Nduka and Harrison (1980). The hemolymph was obtained via a small hole made in the shell directly above the heart and capillary tube was inserted then it was drawn into tube by capillary suction. The collected hemolymph was kept in ice for biochemical parameters analysis.

Biochemical parameters were determined spectrophotometrically using kits purchased from BioMerieux and Boehringer 3.1 Mennheim companies. Total protein was estimated according to the method of Bradford (1976). Transaminase enzymes (ALT and AST) were examined according to the method of Reitman and Frankel (1957). Alkaline phosphatase (ALP) was estimated according to the method of Babson (1965).

\section{Histological effect of $\mathrm{ACuO} \mathrm{NC}$ on hermaphrodite glands of B. alexandrina}

Snails exposed to $\mathrm{LC}_{10}$ and $\mathrm{LC}_{25}$ of $\mathrm{ACuO} \mathrm{NC}$ for two weeks (Bakry, 2009). Three replicates of one hundred snails were prepared for each concentration. Changes in histology of hermaphrodite gland of treated snails compared with control snails were done according to Mohamed and Saad (1990).

\section{Effect of nanocomposites on biological indicator Daphnia magna}

The effect of ACuO NC on Daphnia magna was accomplished by collecting water from natural snail's habitat, transferred to the laboratory and examined microscopically. Daphnia magna was cultured in dechlorinated water in plastic containers and feed daily on yeast. Healthy ones were exposed to $\mathrm{LC}_{10}, \mathrm{LC}_{25}, \mathrm{LC}_{50}$ and $\mathrm{LC}_{90}$ of $\mathrm{ACuO} \mathrm{NC}$. Three replicates of one hundred Daphnia were used for experiment and control (Mostafa, 2006). After exposure time (1/2, 1, 3, 6. 12, 24, 48, 72 and 96 hours), the mortality rates were recorded.

\section{Statistical analysis}

Data were analyzed using statistical package for the social sciences (SPSS, 18). Differences between the untreated and treated samples were tested for significance using a T-test ( $P$ value $<0.05$ was considered statistically significant).

\section{RESULTS AND DISCUSSION}

\section{Characterization nanoparticles}

The scanning electron microscope image provides spherical nanoparticles morphology (Fig. 3A). However, TEM image showed that the CuO NPs have average 
size $29.0 \mathrm{~nm}$ (Fig. 3B). Srivastava et al. (2013) have synthesized CuO NPs with an average particle size16 $\mathrm{nm}$ that observed from TEM image. Moreover, XRF recorded that $98.5 \%$ of the elemental composition of $\mathrm{CuO}$ NPs powder is pure $\mathrm{Cu}$ (Fig. 4).

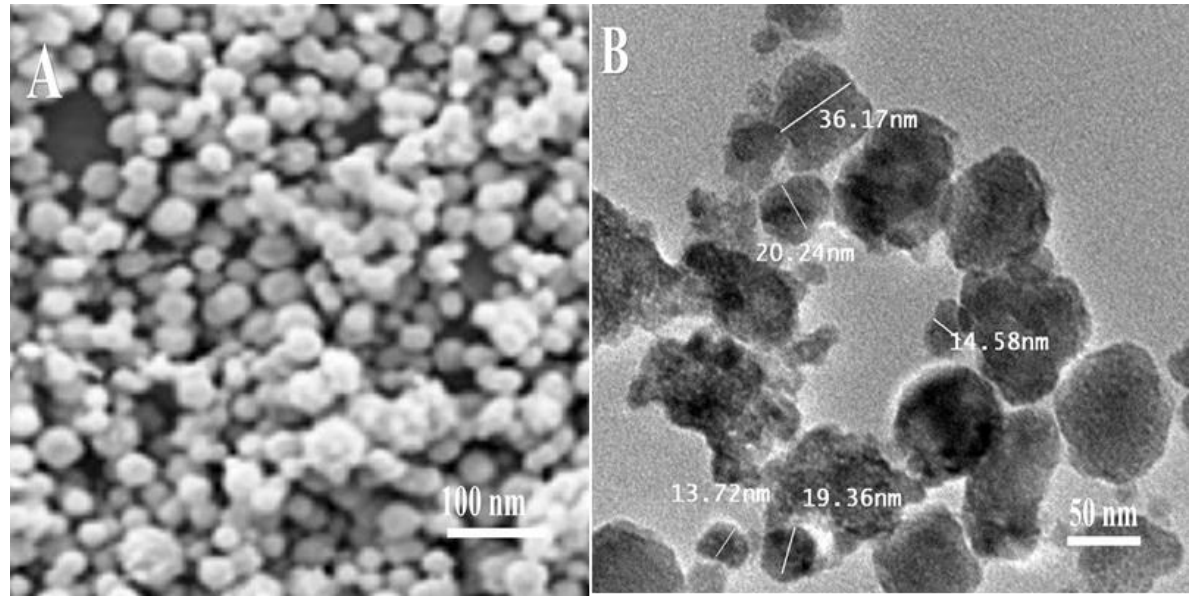

Fig. 3: A) SEM and B) TEM for copper oxide nanoparticles.

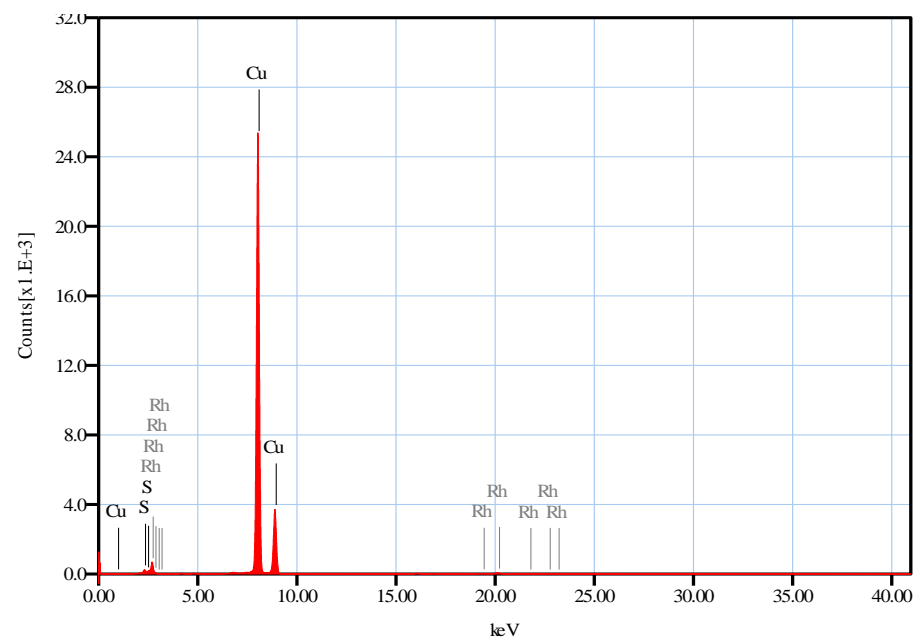

Fig. 4: XRF for copper oxide nanoparticles

The FTIR spectra of ACuO NC composites compared with pure $\mathrm{CuO}$ NPs as shown in Figure (5). Data showed wide and stronger absorption bands at $3854 \mathrm{~cm}^{-1}$, which indicated that the hydroxyl $(-\mathrm{OH})$ functional group is present on the surface of NPs and NC. Moreover, the strong link of $\mathrm{CuO}$ NPs to amide groups of A. arvensis was present. However, the absorption peak at $2926 \mathrm{~cm}^{-1}$ was attributed to asymmetric stretching of $\mathrm{CH}_{3}$ and $\mathrm{CH}_{2}$ of the plant. While the peaks at $1624-1099 \mathrm{~cm}^{-1}$ referred bending vibration of $\left(-\mathrm{NH}_{2}\right)$ group and $(\mathrm{C}-\mathrm{O})$ stretching group. New broad absorption band in the range of $820-494 \mathrm{~cm}^{-1}$ was appeared in the FTIR spectra of $\mathrm{ACuO} \mathrm{NC}$ due to the formation of metal oxygen $(\mathrm{Cu}-\mathrm{O})$ bond. Also, the peaks of $-\mathrm{NH}_{2}, 3^{\prime}-\mathrm{OH}, 5^{\prime}-\mathrm{OH}$ and $\mathrm{C}=\mathrm{O}$ groups were found due to hydrogen bonds between plants and NPs as recorded by Li et al. (2010). 

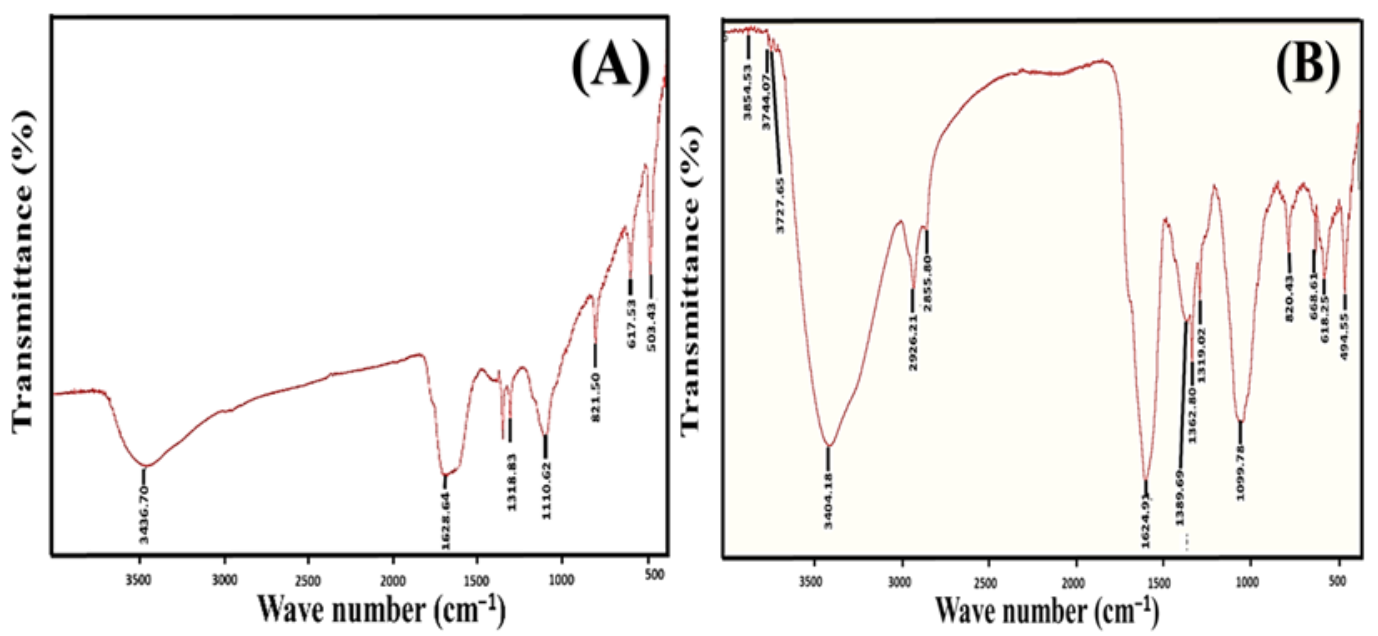

Figure 5: Fourier transform infrared spectroscopy of A) Copper oxide nanoparticles and B) A. arvensis - copper oxide nanocomposite.

\section{Molluscicidal activity of $\mathrm{ACuO}$ NC}

Data from (Table 1) showed that different lethal concentrations of ACuO NC against $B$. alexandrina snails. The results revealed that the molluscicidal activity increased by increasing the concentration. Where, the lethal concentrations $\mathrm{LC}_{50}$ and $\mathrm{LC}_{90}$ of $\mathrm{ACuO} \mathrm{NC}$ were 1.76 and 3.16 ppm, respectively (Fig. 7). However, Ibrahim and Ghoname (2018) showed that low molluscicidal activity of the aqueous leaves extracts of $A$. arvensis against $B$. alexandrina snails with $\mathrm{LC}_{50}$ and $\mathrm{LC}_{90}$ reached to 37.9 and $48.3 \mathrm{ppm}$, respectively. Also, the present data showed that survival rates of adult $B$. alexandrina snails were markedly reduced which may arise from metabolic disorders as a result of saponine compounds present in the plant extracts or the type of solvent used. In most recent studies, the toxicity of $\mathrm{CuO}$ NPs increased when the rate of $\mathrm{Cu}^{++}$ions increased and bioavailability increased in solution (Aruoja et al., 2009; Mortimer et al., 2010).

Table 1: Molluscicidal activity of A. arvensis - nanocomposite against B. alexandrina.

\begin{tabular}{lccccc}
\multirow{2}{*}{ Tested plant NC } & \multicolumn{5}{c}{ Lethal concentrations (ppm) } \\
\cline { 2 - 6 } A. arvensis $-\mathrm{CuO} \mathrm{NC}$ & $\mathrm{LC}_{5}$ & $\mathrm{LC}_{10}$ & $\mathrm{LC}_{25}$ & $\mathrm{LC}_{50}$ & $\mathrm{LC}_{90}$ \\
& 0.18 & 0.35 & 1.01 & 1.76 & 3.16
\end{tabular}

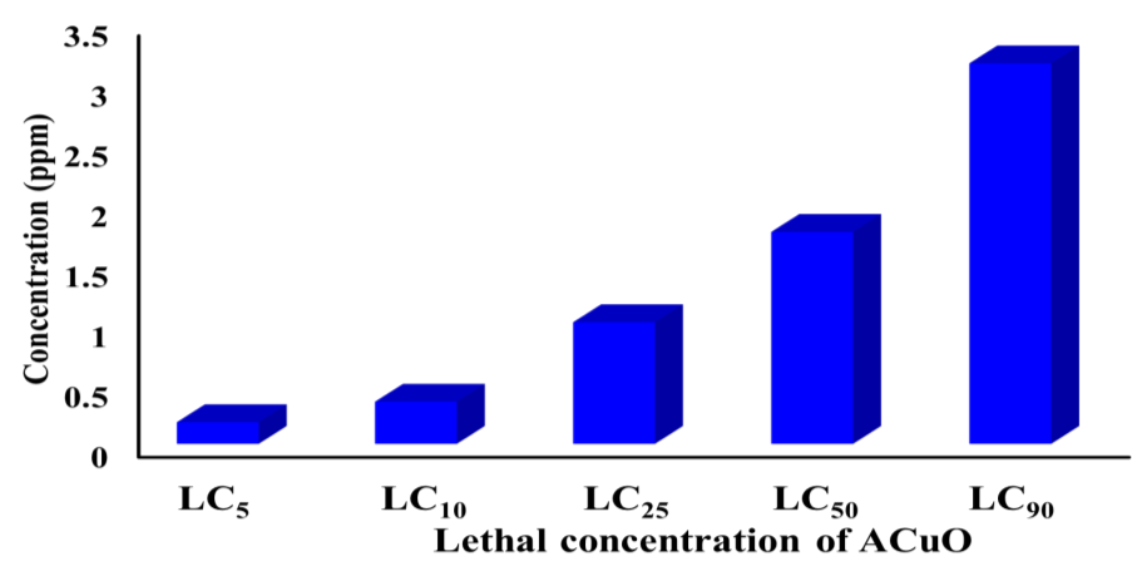

Fig. 7: Lethal concentrations of ACuO NC against Biomphalaria alexandrina snails. 


\section{Effect of some environmental factors on molluscicidal activity of $\mathrm{ACuO} \mathrm{NC}$}

Data from Figure (8) revealed that the molluscicidal activity of $\mathrm{ACuO} \mathrm{NC}$ was increased as the temperature was increased. $\mathrm{LC}_{50}$ of $\mathrm{ACuO} \mathrm{NC}$ was 5.0, 1.76 and 1.0 ppm at 15,25 and $30^{\circ} \mathrm{C}$, respectively. The snail species were highly sensitive to temperature elevation in which may causes thermal stress on snail and reduces the dissolved oxygen content of the water body (Hofkin et al., 1991). Also, El-Emam and Madsen, (1982) observed that the survival of $B$. alexandrina was reduced at temperatures above $33{ }^{\circ} \mathrm{C}$ and below $10{ }^{\circ} \mathrm{C}$.

The data indicated that the molluscicidal activity of $\mathrm{ACuO} \mathrm{NC}$ increased at acidic $\mathrm{pH} . \mathrm{LC}_{50}$ of $\mathrm{ACuO} \mathrm{NC}$ were $0.9,1.79$ and $1.79 \mathrm{ppm}$, respectively at $\mathrm{pH} 4,7$ and 9. (Fig. 8). $\mathrm{pH} 7$ showed the most promising results of the nanocomposite. It was found that nanoparticles were more soluble at $\mathrm{pH} 5$ than at $\mathrm{pH} 7$ and 9, suggesting higher toxicity of the nanoparticles at lower $\mathrm{pH}$ due to the increased release of $\mathrm{M}^{2+}$ ions which indicated that $\mathrm{M}^{2+}$ ions are key agents of toxicity (Bondarenko et al., 2012). The acidic $\mathrm{pH}$ may increase the ability of nanoparticles to penetrate cells and it may prove that toxicity depends on $\mathrm{pH}$ due to the increased solubility of nanoparticles in acidic $\mathrm{pH}$. The increased release of $\mathrm{M}^{2+}$ in acidic $\mathrm{pH}$ may increase the production of reactive oxygen species and affect the mortality of snails (Kaweeteerawat et al., 2015).

The molluscicidal activity of $\mathrm{ACuO} \mathrm{NC}$ decreased as TDS increased, where $\mathrm{LC}_{50}$ of $\mathrm{ACuO} \mathrm{NC}$ was 1.76, 3.07, 7.8 and $20.9 \mathrm{ppm}$ at TDS 300, 600, 900 and 1200 ppm, respectively (Fig. 8). However, Saad et al. (2012) indicated that B. alexandrina snails were found at wide TDS range of (601-1000 ppm). While, Goncalves et al. (2017) indicated that $\mathrm{Cu}^{2+}$ dissolution with inverse salinity dependence, the toxic effects observed for $\mathrm{CuO}$ NPs might be due to intrinsic toxicity mechanisms related to the nanoform and their aggregation plays a key role in their toxicity.

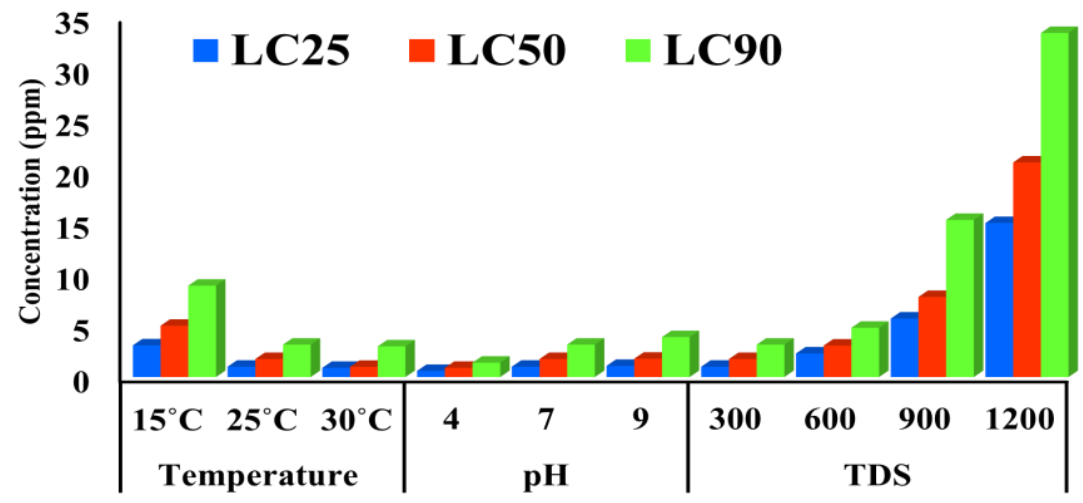

Fig. 8: Effect of temperature, $\mathrm{pH}$ and TDS on molluscicidal activity of $\mathrm{ACuO} \mathrm{NC}$ against B. alexandrina snails.

\section{Effect of $\mathrm{ACuO} \mathrm{NC}$ on biochemical parameters of $B$. alexandrina}

Table (3) showed that the total protein contents of the treated snails were affected with $\mathrm{LC}_{10}$ and $\mathrm{LC}_{25}$ of $\mathrm{ACuO} \mathrm{NC}$. The results revealed a significant reduction in total protein content compared with the control group $(p<0.05)$. It noticed that the reduction in total protein was increased by raising the concentration of nanocomposite (Fig. 9). This decrease in total protein content might due to the physiological adaptation of the snails to compensate the toxic stress which led to the stimulation of protein catabolism (Hasheesh et al., 2011) and determines how various toxic agents affect protein synthesis. This result agreed with result recorded by 
Fahmy et al. (2014), who showed that the total protein contents in the hemolymph of B. alexandrina snails were reduced after their exposure to sublethal concentrations of zinc oxide nanoparticles.

Also, data from (Table 3) revealed that the activities of transaminase enzymes (ALT and AST) and ALP with highly significant elevation in comparison with those of control $(p<0.01$ and $p<0.001)$ (Fig. 9). These results were in agreement with the past investigation of Abdel Kader et al. (2004) who reported severe damages in vital activities of $B$. alexandrina snails when exposed to low doses of synthetic and natural molluscicides.

Table 3: Effect of ACuO NC on some biochemical parameters against B. alexandrina snails.

\begin{tabular}{ccccc}
\hline $\begin{array}{c}\text { Lethal } \\
\text { concentrations }\end{array}$ & Total protein $(\mathrm{g} / \mathrm{l})$ & $\begin{array}{c}\text { ALT } \\
(\mathrm{U} / \mathrm{l})\end{array}$ & $\begin{array}{c}\text { AST } \\
(\mathrm{U} / \mathrm{l})\end{array}$ & $\begin{array}{c}\text { ALP } \\
(\mathrm{U} / \mathrm{L})\end{array}$ \\
\hline Control & $6.00 \pm 0.5$ & $77.2 \pm 6.3$ & $87 \pm 2.8$ & $82.5 \pm 5.5$ \\
& $5.35 \pm 0.4$ & $112 \pm 4.0^{* *}$ & $99 \pm 3.6^{* *}$ & $103 \pm 3.9^{* *}$ \\
$\mathrm{LC}_{10}$ & & $150.7 \pm 8.0^{* * *}$ & $120.4 \pm 3^{* * *}$ & $127 \pm 2.8^{* * *}$ \\
$\mathrm{LC}_{25}$ & $4.57 \pm 0.39^{*}$ &
\end{tabular}

Data is expressed as Mean $\pm \mathrm{SD}$. *Significant compared to control at $p<0.05 ; * *$ highly significant compared to control at $p<0.01 ; * * *$ Very highly significant compared to control at $p<0.001$.
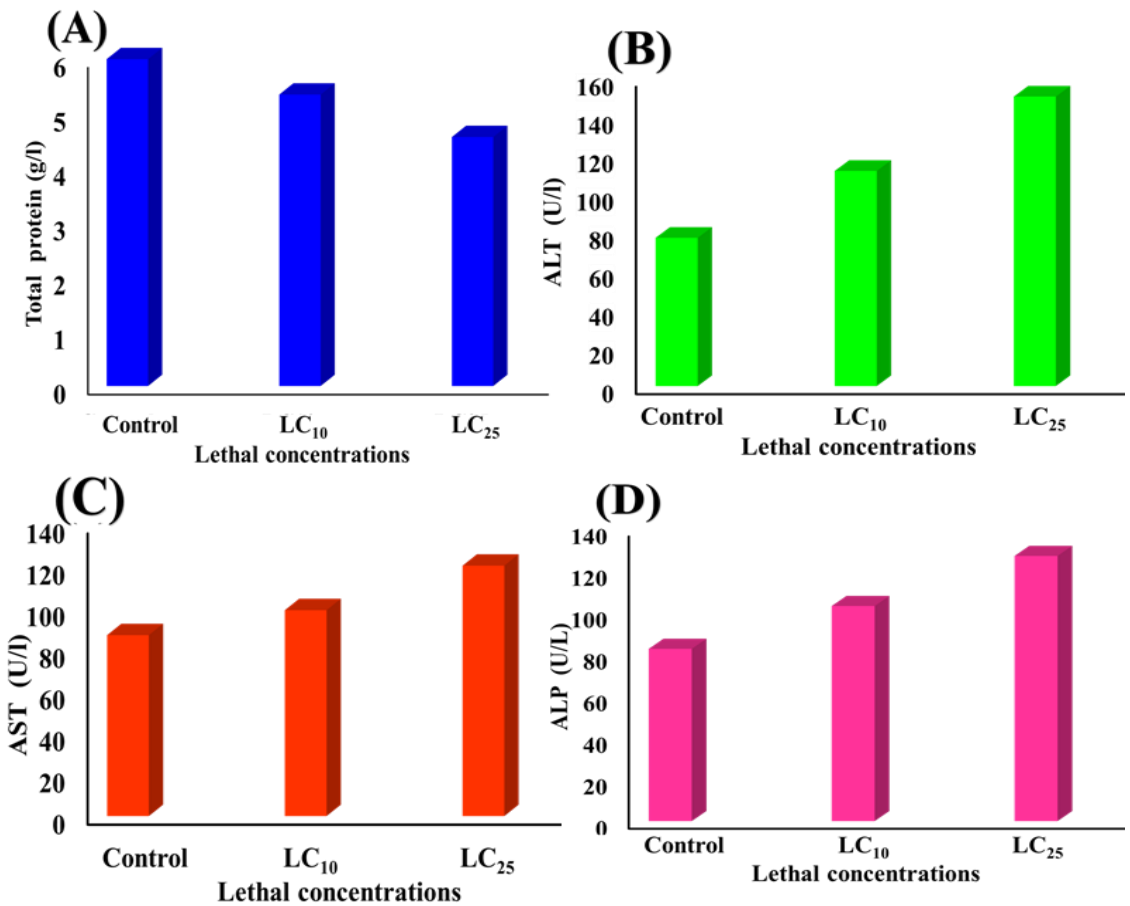

Fig. 9 : Effect of ACuO NC on (A) Total protein, (B) ALT, (C) AST and (D) ALP of treated $B$. alexandrina snails compared with control group.

\section{Effect of $\mathrm{ACuO} \mathrm{NC}$ on hermaphrodite glands of $\mathrm{B}$. alexandrina}

The hermaphrodite gland of $B$. alexandrina snails was detected by light microscope, where the normal hermaphrodite gland (control) showed spermatogenesis and oogenesis stages (Fig. 10, A). Snails exposed to $\mathrm{LC}_{10}$ of $\mathrm{ACuO}$ NC showed moderate changes in the hermaphrodite gland structure. Most of the primary oocytes degenerated and became crumpled. Sperms degenerated and scattered in acinus (Fig. 10, B). While, snails exposed to $\mathrm{LC}_{25}$ of $\mathrm{ACuO} \mathrm{NC}$ suffered from great damage in gonadal cells represented by degenerated mature ova and sperms (Fig. 10, C). These results were in agreement with El-Khayat et al. (2018), 
who indicated that the hermaphrodite gland of $B$. alexandrina infected treated with the plant extract of $A$. arvnsis showed induced degeneration and disappearance in the gonadal cells with severe deformation, destruction in the reproductive units and severe suppression when evacuations occur in many gonads cells.

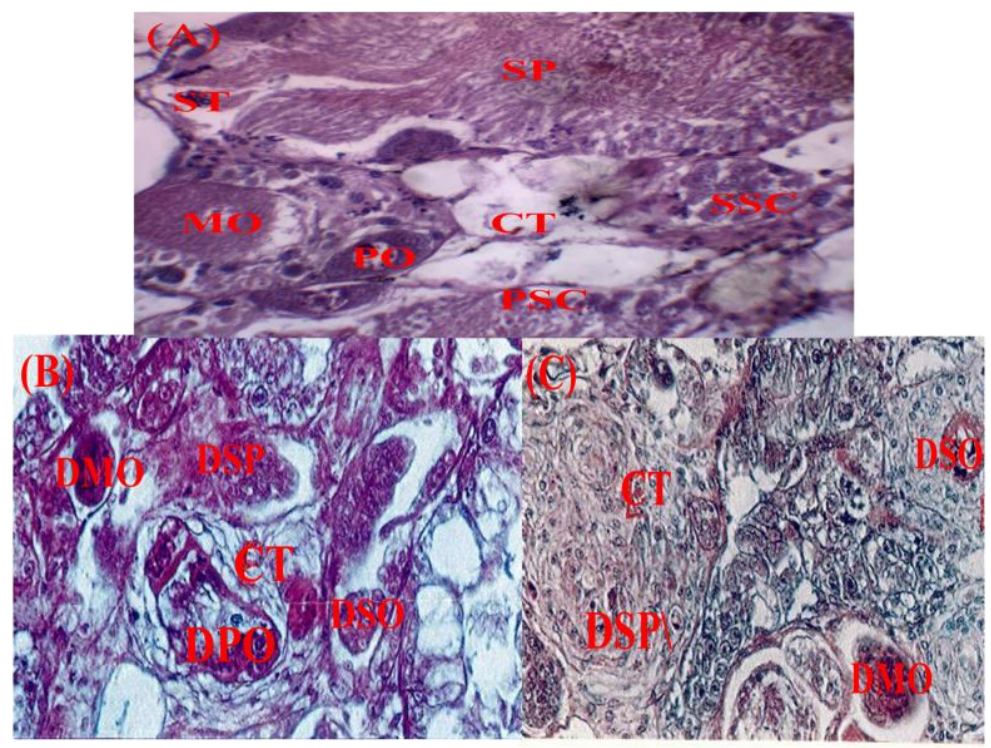

Fig. 10: Light micrograph showing sections in hermaphrodite glands of snails exposed to A. arvensis $\mathrm{CuO}$ nanocomposite $(\times 400)$ : (A) normal B. alexandrina snails showing connective tissue $(\mathrm{CT})$, mature ova (MO), secondary oocyte (SO), primary spermatocytes (PSC), secondary spermatocytes (SSC), sperms (SP) and spermatids (ST). (B) Snails exposed to $\mathrm{LC}_{10}$ of the composite, degenerated mature ova (DMO), degenerated primary oocyte (DPO), degenerated secondry oocyte (DSO) and degenerated sperms (DSP). (C) Snails exposed to $\mathrm{LC}_{25}$ of the composite.

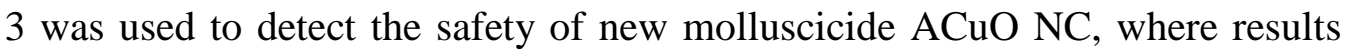
showed that $\mathrm{LC}_{10}$ of $\mathrm{ACuO} \mathrm{NC}$ caused very lower mortality for $D$. magna by $4 \%$ after 96 hours of exposure. However, the $\mathrm{LC}_{25}$ recorded $11 \%$ mortality, after the same time. While $\mathrm{LC}_{50}$ represented $20 \%$ mortality after 96 hours of exposure. On the other hand, $\mathrm{LC}_{90}$ of $\mathrm{ACuO} \mathrm{NC}$ caused $100 \%$ mortality after 4 hours (Fig. 11). Karlsson et al. (2008) explained the toxicity of $\mathrm{CuO}$ nanoparticles that may be attributed to the release of $\mathrm{Cu}^{+2}$ ions. Also, Abdel Kader et al. (2003) showed that $A$. arvensis has the least toxic effect on Daphnia pulex than C. micrantha and Bayluscide.

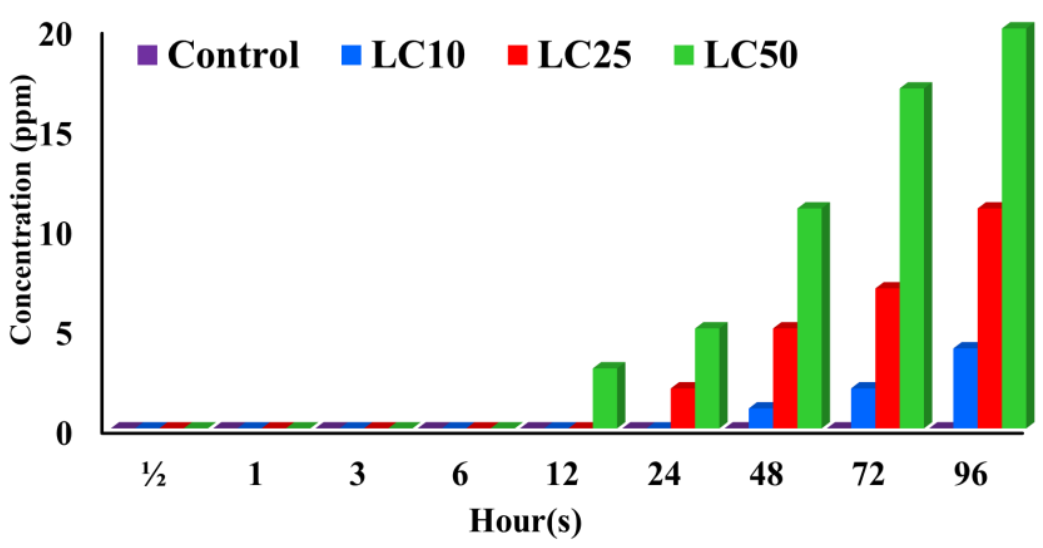

Fig. 11: Effect of Lethal concentrations of ACuO NC on Daphnia magna. 


\section{CONCLUSION}

It can be concluded that the present study succeeded in improving the molluscicidal activity of $A$. arvensis extract fabricated new $\mathrm{ACuO}$ agent nanocomposite with promising molluscicidal activity. This new molluscicide has high significant alterations in the biochemical and histopathological aspects in the freshwater snail B. alexandrina the intermediate host of Schitosoma mansoni. It is advisable to use such nanocomposite in schistosomiasis control planning to limit water contamination as it is inexpensive and environmentally safe, where it showed very high molluscicidal activity with more safety against Daphnia magna as an indicator of water contamination.

\section{ACKNOWLEDGMENTS}

The authors gratefully thank the Environmental Researches Department, Theodor Bilharz Research Institute, Egypt for all of the support provide.

\section{REFERENCES}

Abdel-Ghaffar, F.; Ahmed, A.K.; Bakry, F.; Rabei, I. and Ibrahim, A. (2016): The impact of three herbicides on biological and histological aspects of Biomphalaria alexandrina intermediate host of Schistosoma mansoni. Malacologia, 59(2): 197-210.

Abdel Kader, A.; Mostafa, B.B.; Ragab, F.M.A.; El-Said, K.M.; Tantawy, A.A. and El - Khayat, H.M.M. (2003): Influence of some natural and synthetic substances on certain fresh water organisms and the snail vectors of schistosomiasis and fascioliasis. Egypt. J. Schistosomiasis infec. Endem. 25:83.

Abdel Kader, A.; Ramzy, M.T. and Tantawy, A.A. (2004): Evaluation of the molluscicidal and in vitro schistosomicidal activity of butanol extract of the plant Agave filifera. Egypt J Biomed Sci 16:53-67.

Abou-El-Naga, I.F.; El-Nassery, S.M.F.; Allam, S.R.; Shaat, E.A. and Mady, R.F.M. (2011). Biomphalaria species in Alexandria water channels. Parasitol Int. 60: 247-254.

Adewumi, A.A.J.; Aina, V.O. and Zhang, C.S.Z. (2013): Assessment of the molluscicidal activities of Sasanqua saponin. Curr. Res. J. Biol. Sci., 5:1-4.

Ali, D.; Alarifi, S.; Kumar, S.; Ahamed, M. and Siddiqui, M.A. (2012): Oxidative stress and genotoxic effect of zinc oxide nanoparticles in freshwater snail Lymnaea luteola L. Aquat Toxicol., 124-125:83-90.

Andrievsky, G.V.; Klochkov, V.K.; and Derevyanchenko, L.I. (2005): Is C60 Fullerene Molecule Toxic?! Fullerenes, Nanotubes, Carbon Nanostructures. 4(13): 363-376.

Aruoja, V.; Dubourguier, H.C.; Kasemets, K. and Kahru, A. (2009): Toxicity of nanoparticles of $\mathrm{CuO}, \mathrm{ZnO}$ and $\mathrm{TiO}_{2}$ to microalgae Pseudokirchneriella subcapitata. Sci. Total Environ. 407: 1461-1468.

Babson, L.A. (1965): Phenolphalein monophosphate methods for the determination of alkaline phosphatase. Clin. Chem. 11: 789-796.

Bakry, F.A. (2009): Impact of some plant extracts on histological structure and protein patterns of Biomphalaria alexandrina snails. Global Journal of Molecular Sciences, 4(1): 34-41. 
Bakry, F.A.; Ragab, F.M.A. and Sakran, A.M.A. (2002): Effect of some plant extracts with molluscicidal properties on some biological and physiological parameters of Biomphalaria alexandrina snails. Journal of Egyptian German Society of Zoology. 38: 101-111.

Bilharz, T. (1853): Further observations concerning Distomum haematobium in the portal vein of man and its relationship to certain pathological formations with brief notes by Seibald. Z Wiss Zool. 1853, 4:72.

Bondarenko, O.; Ivask, A.; Käkinen, A. and Kahru, A. (2012): Sub-toxic effects of $\mathrm{CuO}$ nanoparticles on bacteria: Kinetics, role of $\mathrm{Cu}$ ions and possible mechanisms of action. Environ. Pollut. 169: 81-89.

Borai, I.H.; Farag, A.A.; Moselhy, S.S. and El-Behary, M.H. (2005): Effect of some formulated plant extracts on snails of Schistosomiasis and study their biological effects. Master degree in Environmental Science Department of Suez canal university of Biological \& Natural Sciences.

Bradford, M.M. (1976): A rapid and sensitive method for the quantitation of microgram quantities of protein utilizing the principle of protein-dye binding. Anal. Biochem. 72: 248-254.

El-Emam, M. and Madsen, H. (1982): The effect of temperature, darkness, starvation and various food types on growth, survival and reproduction of Helisoma duryi, Biomphalaria alexandrina and Bulinus truncatus (Gastropoda: Planorbidae). Hydrobiologia 88: 265-275.

El-Ghany, A.M.A. and El-Ghany, N.M.A. (2017): Molluscicidal activity of Bacillus thuringiensis strains against Biomphalaria alexandrina snails. Beni-Suef Univ. J. Basic Appl. Sci. 6(4): 391-393.

El-khyat, H.M.M.; Mohamed, K.M.; Ahmed, N.A. and Mohamed, H.E. (2018): Histopathological and ultrastructural studies on Biomphalaria alexandrina snails infected with Schistosoma mansoni miracidia and treated with plant extracts. The Egyptian journal of hospital medicine 71(3): 2792-2804.

Elsareh, F.; Abdalla, R. and Abdalla, E. (2016): The effect of aqueous leaves extract of Solenostemma argel (Del Hayne) on egg masses and neonates of Biomphalaria pfeifferi snails. J. Med. Plants. 4: 271-274.

Fahmy, S.R.; Abdel-Ghaffar, F.; Bakry, F.A. and Sayed, D.A. (2014): Ecotoxicological effect of sublethal exposure to zinc oxide nanoparticles on freshwater snail Biomphalaria alexandrina. Arch Environ Contam Toxicol. 67(2): 192-202.

Gonçalves, M. F. M.; Gomes, S. I. L.; Scott-Fordsmand, J. J. and Amorim, M. J. B. (2017): Shorter lifetime of a soil invertebrate species when exposed to copper oxide nanoparticles in a full lifespan exposure test. Sci. Rep. 7:1355.

Habib, M.R.; Mohamed, A.H.; Osman, G.Y.; Mossalem, H.S.; Sharaf El-Din, A.T. and Croll, R.P. (2016): Biomphalaria alexandrina as a bioindicator of metal toxicity. Chemosphere.157:97-106.

Handy, R.D.; Kammer, F.V.D. ; Lead, J.R.; Hassellov, M.; Owen, R. and Crane, M. (2008): The ecotoxicity and chemistry of manufactured nanoparticles. Ecotoxicology. 17: 287-314.

Hasheesh, W.S; Marie, M.A.S.; El-Deeb, F.A.A. and Sayed S.S.M. (2011): Impact of Asparagus densiflours and Oreopanax guatemalensis plants and difenoconazole fungicide on biochemical parameters of Biomaphalaria alexandrina snails. Austral J. Basic Appl. Sci. 5:366-37. 
Hofkin, B.V.; Mkoji, G.M.; Koech, D.K. and Loker, E.S. (1991): Control of schistosome-transmitting snails in Kenya by the North American crayfish Procambarus clarkii. Am. J. Trop. Med. Hyg. 45: 339-344.

Ibrahim, A.M. and Abdalla, A.M. (2017): Impact of Moringa oleifera seed aqueous extract on some biological, biochemical, and histological aspects of Biomphalaria alexandrina snails. Environ. Sci. Pollut. Res. Int. Dec. 24(36):28072-28078.

Ibrahim, A.M. and Ghoname, S.I. (2018): Molluscicidal impacts of Anagallis arvensis aqueous extract on biological, hormonal, histological and molecular aspects of Biomphalaria alexandrina snails. Experimental Parasitology 192:36-41.

Jagtap, J.T.; Shejule, K.B. and Jaiswal, D.P. (2011): Acute toxicity study of tributyltin chloride on the freshwater bivalve, Lamellidens marginalis. World. Fish Mar. Sci. 3(2):100-103.

Karlsson, H.L.; Cronholm, P.; Gustafsson, J.; Moller, L. (2008): Copper oxide nanoparticles are highly toxic:A comparison between metal oxide nanoparticles and carbon nanotubes. Chem. Res. Toxicol. 21:1726-1732.

Kaweeteerawat, C.; Chang, C.H.; Roy, K.R.; Liu, R.; Li, R.; Toso, D.; Fischer, H.; Ivask, A.; Ji, Z. and Zink, J.I. (2015): Cu nanoparticles have different impacts in Escherichia coli and Lactobacillus brevis than their microsized and ionic analogues. ACS. Nano. 9: 7215-7225.

Krysanov, E.Y.; Pavlov, D.S.; Demidova, T.B. and Dgebuadze Y.Y. (2010): effect of nanoparticles on aquatic organisms. Biology Bulletin, 4(37): 406-412.

Lee, K.S.; Rao, S.P.; Moon, M. H. and Gidding, J.C. (1996): Determination of mean diameter and particle size distribution of acrylate latex using flow field-flow fractionation, photon correlation spectroscopy and electron microscopy. Anal. Chem. 68: $1545-1549$.

Lemma, A. (1970): Laboratory and field evaluation of molluscicidal properties of phytolacca dodecandra. Bull WHO, 42: 597-612.

Li, L.H.; Deng, J.C.; Deng, H.R.; Liu, Z.L. and Xin, L. (2010): Synthesis and characterization of chitosan/ $\mathrm{ZnO}$ nanoparticle composite membranes. Carbohydr. Res., 345(8): 994-998.

Ma, H.; Williams, P.L. and Diamond, S.A. (2013): Ecotoxicity of manufactured ZnO nanoparticles-A review. Environ. Pollut., 172:76-85.

Manyasree, D.; Kiran, M.P. and Ravikumar R. (2017): CuO nanoparticles: synthesis, characterization and their bactericidal efficacy. Int. J. of App. Pharm. 9 (6):7174.

Mohamed, S.H. and saad, A.A. (1990): Histological studies on the hermaphrodite gland of Limnaea cailaudi and Biomphalaria alexandrina upon infection with certain larval trematodes. Egy. J. of Histology. 13: 47-53.

Mortimer, M; Kasemets, K. and Kahru, A. (2010): Toxicity of $\mathrm{ZnO}$ and $\mathrm{CuO}$ nanoparticles to ciliated protozoa Tetrahymena thermophila. Toxicology. 269: 182-189.

Mostafa, B.B. (2006): Effect of three dormant oils on Schistosomiasis and Fascioliasis vector snails and its relation with some non - target snails. J. Egypt. Soc. Parasitol. 36: 809-826.

Nduka, W.K. and Harrison, A.D. (1980): Cationic responses of organs and haemolymph of Biomphalaria pfeifferi (Krauss), Biomphalaria glabrata (Say) and Helisoma trivolvis (Say) (Gastropoda: Planorbidae) to cationic alterations of the medium. Hydrobiologia. 68: 119-138. 
Nolan, M.O.; Howard W.B. and Elizabeth, R.M. (1953): Results of laboratory screening tests of chemical compounds for molluscicidal activity. Amer. J. Trop. Med. Hyg., 22: 716-752.

Nowack, B. (2009): The behavior and effects of nanoparticles in the environment. Environ. Pollut, 157: 1063-1064.

Oberdorster G., Oberdorster E., Oberdorster, J. (2005): Nanotoxicology: an emerging discipline evolving from studies of ultrafine particles. Environ Health Perspect, 113: 823-839.

Oberdorster G' S.V., Donaldson K, (2007): Toxicology of nanoparticles: a historical perspective. Nanotoxicology: 1(1): 2-25.

Park, S. and Choi, J. (2010): Geno and ecotoxicity evaluation of silver nanoparticles in freshwater Crustacean Daphnia magna. Environ. Eng. Res. 15(1):23-27.

Pavlica, M.; Klobucar, G.I.V.M.; Vetma, N.; Erben, R. and Papes, D. (2000): Detection of micronuclei in haemocytes of zebra mussel and great ramshorn snail exposed to pentachlorophenol. Mutat. Res. 46:145-150.

Reitman, S. and Frankel, S. (1957): Acolorimetric method for the determination of serum glutamic oxalacetic and glutamic pyruvic transaminases. Am. J. Clin. Pathol. 28(1): 56-63.

Rostami-Vartooni, A.; Alizadeh, M. and Bagherzadeh, M. (2015): Green synthesis, characterization and catalytic activity of natural bentonite-supported copper nanoparticles for the solvent-free synthesis of 1-substituted $1 \mathrm{H}-1,2,3$, 4tetrazoles and reduction of 4-nitrophenol. Beilstein J. Nanotechnol. 6:23002309.

Saad, A.E.A.; Mostafa, B.B.; El-Magd, S.S.A. and Azzam, A.M.A. (2012): Impact of some environmental factors on distribution of certain vector snails in five Egyptian Governorates. Egypt. J. Aquat. Biol. \& Fish. 16 (1):33-40.

Salah El-Din, M.A. (1999): Toxicological and physiological effects of ammonia on Grass Carp Ctenopharyngodon idella at different $\mathrm{pH}$ levels. Egypt. J. Zool. 33,219 .

Sales, J. (2013): Effects of pharmacological concentrations of dietary zinc oxide on growth of post-weaning pigs: A meta-analysis. Biol. Trace Elem. Res. 152(3):343-349.

Shi, X.Y. and Fan, X.G. (2002): Advances in nanoparticles system for delivering drugs across the biological barriers. J China Pharm University; 33(3):169-172.

Sminia T. (1972): Structure and function of blood and connective tissue cells of the fresh water pulmonate Lymnaea stagnalis studied by electron microscopy and enzyme histochemistry. Z. Zellforsch., 130: 497-526.

Srivastava, S.; Kumar, M.; Agrawal, A. and Dwivedi, S.K. (2013): Synthesis and characterization of copper oxide nanoparticles. IOSR J. of applied physics, 5(4): 61-65.

Sun, Y.; Fang, L.; Wan, Y. and Gu, Z. (2018): Pathogenic detection and phenotype using magnetic nanoparticle-urease nanosensor. Sensors and Actuators B: Chemical, 259: 428-432.

Wang, L.; Hu, C. and Shao, L. (2017): The antimicrobial activity of nanoparticles: present situation and prospects for the future. International Journal of Nanomedicine, 12: 1227-1249.

Wetzel, R. G. (2001): Limnology: Lake and River Ecosystems. $3^{\text {rd }}$ ed., San Diego, CA: Academic Press.

WHO (1965): Molluscicide screening and evaluation. Bull. W.H.O. 33: 567-581

WHO (2014): Schistosomiasis. Fact Sheet No. 115. 
WHO (2017): Schistosomiasis. Fact Sheet 115. Updated Oct.

Wiench, K.; Wohlleben, W.; Hisgen, V.; Raske, K.; Salinas, E. and Zok, S. (2009): Acute and chronic effects of nano- and non-nanoscale $\mathrm{TiO}_{2}$ and $\mathrm{ZnO}$ particles on mobility and reproduction of the freshwater invertebrate Daphnia magna. Chemosphere. 76: 1356-1365.

\section{ARABIC SUMMARY}

\section{تحسين النشاط الإبادى لمستخلص نبات Anagalis arvensis باستخدام اكسيد النحاس النانومترى تجاه قواقع Biomphalaria alexandrina}

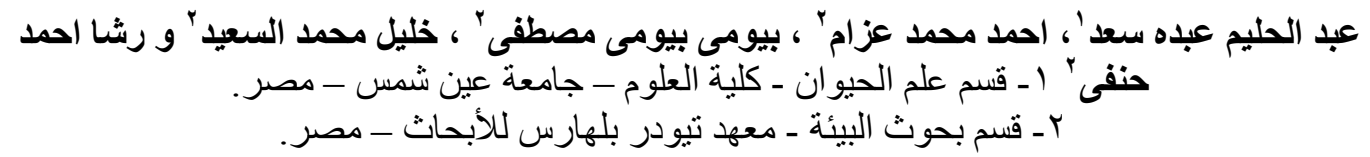

ز اد الاهتمام حديثاً بتطبيقات النانوتكنولوجى حيث تم إختبار بعض الجزيئات النانومنرية كمبيدات لقو اقع

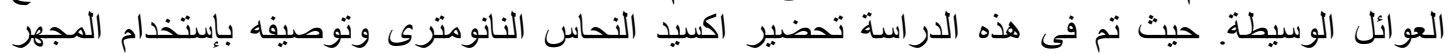

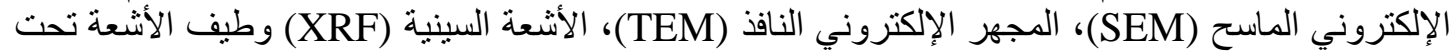

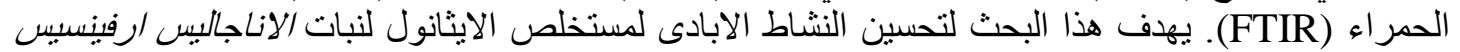
باضافة اكسيد النحاس النانومترى لتكوين مركب نباتى نانومترى (FCuO). المركب لله تاثير إبادى كبير تجاه قواقع بيومفلاريا الكسندرينا حيث كانت قيم التركيزات ات المميتة (LC)

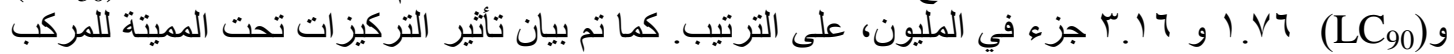

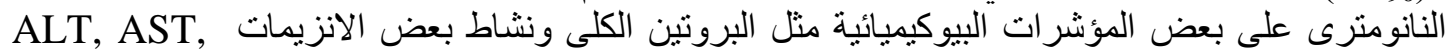
ALP أوضحت الدر استة الهستولوجية للقو اقع المعالجة بالتركيزات تحت الميتة (LCP

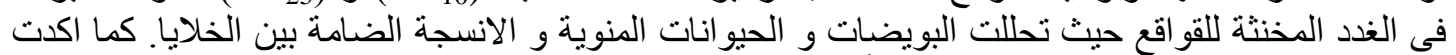

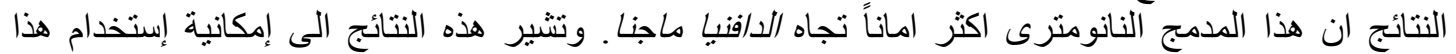

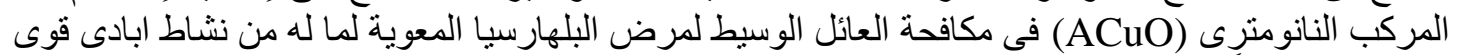
وفعال و اكثر امناً على البيئة المائية. 